\title{
SISTEM INFORMASI JASA ANTARAN KURIR BERBASIS CLIENT SERVER PADA PT. SEMPURNA JASA KAMI/eXis BANDUNG
}

\author{
Ahmad Sahi., S.Kom., M.Kom \\ Dosen Program Studi Manajemen Informatika \\ Politeknik LP3I Bandung \\ Email :oi.asahi@gmail.com
}

\begin{abstract}
Abstrak : Penelitian ini berjudul, Sistem Informasi Jasa Antaran Kurir Berbasis Client Server pada PT. Sempurna jasa kami/exis Bandung". Masalah-masalah yang terjadi meliputi pada bagian data entri, dalam keamanan data, desain setiap form aplikasi, pembuatan laporan masih bersifat manual sehingga kinerja di bagian entri data kurang efektif dan efisien. Tujuan dilakukannya penelitian ini untuk memberikan kontribusi dalam penyelesaian masalah yang dihadapi oleh bagian entri data serta memperbaiki sistem yang sedang berjalan dengan mengusulkan sistem usulan.
\end{abstract}

Sistem usulan meliputi proses input data dan pencarian data pelanggan, data penerima, data kurir, data wilayah, data jenis antaran, data tarif, data status kirim. Proses transaksi data bukti serah terima (BST) dan transaksi Bukti terima Penerima (BtPenerima). Pembuatan laporan data pelanggan, laporan data penerima, laporan data kurir, laporan data hasi kirim serta pembuatan formulir bukti terima (BT).

Metode yang digunakan penulis dalam penelitian ini adalah dengan metode deskriptif dan untuk perancangan sistemnya menggunakan metode waterfall. Sedangkan metode yang digunakan penulis dalam pengumpulan data meliputi observasi partisipan, studi pustaka dan wawancara.

Dengan diusulkannya Sistem Informasi Jasa Antaran Kurir ini diharapkan dapat meningkatkan kinerja PT.Sempurna Jasa Kami/eXis menjadi efektif, efisien, akurat dan lebih baik.

Kata Kunci : Sistem Informasi, kurir, waterfall

\section{Pendahuluan}

Kemajuan teknologi Informasi semakin hari semakin berkembang dan kita dituntut untuk selalu mengikuti perkembangannya, tidak sedikit dari instansi atau perusahaan yang memanfaatkan dari perkembangan teknologi informasi ini, teknologi informasi sudah dijadikan bagian yang penting dari proses pekerjaan, karena kecepatan, kemudahan dan keakuratannya sangat membantu dalam proses penyelesaian pekerjaan, dimana instansi atau perusahaan dituntut untuk menyelesaikan setiap pekerjaannya dengan cepat dan akurat.

PT. Sempurna Jasa Kami/eXis merupakan perusahaan yang bergerak dalam bidang jasa yang hadir khusus untuk memenuhi kebutuhan jasa pengiriman surat, dokumen dan paket dalam wilayah Kotamadya \& Kabupaten Bandung dan luar 
kota. eXis Courier and Delivery Service (eCS) khusus melayani surat, dokumen dan paket dalam waktu 3 hingga 4 hari kerja. Sistem pengantaran dan harga eCS berdasarkan jenis kebutuhan pelanggan (Customized Delivery Service).

Pada saat ini sistem yang berjalan di PT. Sempurna Jasa Kami/eXis mempunyai dua aplikasi yang terpisah dalam pemrosesan data seperti entri data dan pembuatan laporan. Untuk entri data menggunakan aplikasi Visual Basic dan proses pembuatan laporan menggunakan aplikasi web Kondisi ini terjadi karena PT. Sempurna Jasa Kami/eXis ingin memberikan kemudahan kepada para pelanggan untuk mengetahui kondisi laporan hasil pengiriman secara online di internet.

Akan tetapi, pada kenyataannya melihat kondisi para pelanggan tidak semuanya online di internet setiap saat, dan kebanyakan pelanggan ingin memperoleh laporan dalam bentuk dokumen (printout). Sedangkan untuk mengetahui data hasil kiriman melalui internet membutuhkan biaya dan waktu.

Akibat dari sistem informasi yang terpisah karyawan PT. Sempurna Jasa Kami/eXis dalam proses pembuatan laporan terjadi pemindahan data dari aplikasi yang berbeda, yaitu dari aplikasi Web ke aplikasi Microsoft Excel dengan proses copy dan edit. Selain itu juga dalam tampilan setiap form (interface) kurang menarik.

Berdasarkan pemaparan diatas bermaksud untuk memperbaiki beberapa sistem yang sudah ada dengan sistem yang lebih efektif dan efisien, Untuk itu judul laporan tugas akhir ini yaitu "Sistem Informasi Jasa Antaran Kurir Berbasis Client Server Pada Pt. Sempurna Jasa Kami/Exis Bandung”.

\section{Kajian Pustaka}

\subsection{Sistem}

Setiap sistem dibuat untuk menangani sesuatu yang berulang kali atau yang secara rutin terjadi. Pendekatan sistem merupakan suatu filsafat atau persepsi tentang struktur yang mengkoordinasikan kegiatan-kegiatan dan operasi-operasi dalam suatu organisasi dengan cara yang efisien dan yang paling baik. Suatu sistem dapat dirumuskan sebagai setiap kumpulan komponen atau subsistem yang dirancang untuk mencapai suatu tujuan.

Sutabri (2003:8) mengungkapkan bahwa "Sistem adalah sekelompok unsur yang erat hubungannya satu dengan yang lain, yang berfungsi bersama-sama untuk mencapai tujuan tertentu".

Sutabri (2003:11) mengungkapkan bahwa model umum sebuah sistem adalah input, process dan output. Hal ini merupakan konsep sebuah sistem yang sangat sederhana sebab sebuah sistem dapat mempunyai beberapa masukan dan keluaran. Selain itu, sebuah sistem memiliki karakteristik atau sifat-sifat tertentu, yang mencirikan bahwa hal tersebut bisa dikatakan sebagai suatu sistem. Adapun karakteristik yang dimaksud adalah sebagai berikut:

a. Komponen Sistem (Components) 
Suatu sistem terdiri dari sejumlah komponen yang saling berinteraksi, artinya saling bekerja sama membentuk suatu kesatuan. Komponen-komponen sistem tersebut dapat berupa suatu bentuk subsistem. Setiap subsistem memiliki sifat dari sistem yang menjelaskan suatu fungsi tertentu dan mempengaruhi proses sistem secara keseluruhan. Suatu sistem dapat mempunyai sistem yang lebih besar, yang disebut "supra sistem".

b. Batasan sistem (Boundary)

Ruang lingkup sistem merupakan daerah yang membatasi antara sistem dengan sistem yang lain atau sistem dengan lingkungan luarnya. Batasan sistem ini memungkinkan suatu sistem dipandang sebagai suatu kesatuan yang tidak dapat dipisah-pisahkan.

c. Lingkungan Luar Sistem (Environment)

Bentuk apapun yang ada di luar lingkup atau batasan sistem yang mempengaruhi operasi sistem tersebut disebut lingkungan luar sistem. Lingkungan luar sistem ini dapat bersifat menguntungkan dan dapat juga bersifat merugikan sistem tersebut. Lingkungan luar yang menguntungkan merupakan energi bagi sistem tersebut. Dengan demikian, lingkungan luar tersebut harus tetap dijaga dan dipelihara. Lingkungan luar yang merugikan harus dikendalikan. Kalau tidak, maka akan mengganggu kelangsungan hidup sistem tersebut.

d. Penghubung Sistem (Interface)

Media yang menghubungkan sistem dengan subsistem lain disebut penghubung sistem atau interface. Penghubung ini memungkinkan sumbersumber daya mengalir dari satu subsistem ke subsistem yang lain. Bentuk keluaran dari satu subsistem akan menjadi masukan untuk subsistem lain melalui penghubung tersebut. Dengan demikian, dapat terjadi suatu integrasi sistem yang membentuk satu kesatuan.

e. Masukan Sistem (Input)

Energi yang dimasukan ke dalam sistem disebut masukan sistem yang dapat berupa pemeliharaan (maintenance input) dan sinyal (signal input). Contoh, di dalam suatu unit sistem komputer. "Program" adalah maintenance input yang digunakan untuk mengoperasikan komputernya dan "data" adalah signal input untuk diolah menjadi informasi.

f. Keluaran Sistem (Output)

Hasil energi yang diolah dan diklasifikasikan menjadi keluaran yang berguna. Keluaran ini merupakan masukan bagi subsistem yang lain. Contoh, sistem informasi. Keluaran yang dihasilkan adalah informasi. Informasi ini dapat digunakan sebagai masukan untuk pengambilan keputusan atau hal-hal lain yang menjadi input bagi subsistem lain.

g. Pengolahan Sistem (Process)

Suatu sistem dapat mempunyai suatu proses yang akan mengubah masukan menjadi keluaran.

h. Sasaran Sistem (Objective)

Suatu sistem memiliki tujuan dan sasaran yang pasti dan bersifat deterministik. Kalau suatu sistem tidak memiliki sasaran, maka operasi sistem tidak ada gunanya. Suatu sistem dikatakan berhasil bila mengenai sasaran atau tujuan yang telah direncanakan 
Sutabri (2003:13) mengungkapkan bahwa Sistem merupakan suatu bentuk integrasi antara satu komponen dengan komponen lain karena sistem memiliki sasaran yang berbeda untuk setiap kasus yang terjadi yang ada di dalam sistem tersebut. Oleh karena itu, sistem dapat diklasifikasikan dari beberapa sudut pandangan, di antaranya:

a. Sistem abstrak dan sistem fisik

Sistem abstrak adalah sistem yang berupa pemikiran atau ide-ide yang tidak tampak secara fisik, misalnya sistem teologia, yaitu sistem yang berupa pemikiran hubungan antara manusia dengan Tuhan, sedangkan sistem fisik merupakan sistem yang ada secara fisik, misalnya sistem komputer, sistem produksi, sistem penjualan, sistem administrasi personalia, dan lain sebagainya.

b. Sistem alamiah dan sistem buatan manusia

Sistem alamiah adalah sistem yang terjadi melalui proses alam, tidak dibuat oleh manusia, misalnya sistem perputaran bumi, terjadinya siang dan malam, pergantian musim. Sedangkan sistem pembuatan manusia merupakan sistem yang melibatkan interaksi manusia dengan mesin, yang disebut human machine system. Sistem informasi berbasis komputer merupakan contoh human machine system karena menyangkut penggunaan komputer yang berinteraksi dengan manusia.

c. Sistem deterministik dan sistem probabilistik

Sistem yang beroperasi dengan tingkah laku yang dapat diprediksi disebut sistem deterministik. Sistem komputer adalah contoh dari sistem yang tingkah lakunya dapat dipastikan berdasarkan program-program komputer yang dijalankan. Sedangkan sistem yang bersifat probabilistik adalah sistem yang kondisi masa depannya tidak dapat diprediksi karena mengandung unsur probabilistik.

d. Sistem terbuka dan sistem tertutup

Sistem tertutup merupakan sistem yang tidak berhubungan dan tidak terpengaruh oleh lingkungan luarnya. Sistem ini bekerja secara otomatis tanpa campur tangan pihak luar. Sedangkan sistem terbuka adalah sistem yang berhubungan dan dipengaruhi oleh lingkungan luarnya. Sistem ini menerima masukan dan menghasilkan keluaran untuk subsistem lainnya.

\subsection{Daur Hidup Sistem}

Sutabri (2003:14) mengungkapkan bahwa Siklus hidup sistem (system life cycle) adalah proses evolusioner yang diikuti dalam menerapkan sistem atau subsistem informasi berbasis komputer. Siklus hidup sistem terdiri dari serangkaian tugas yang erat mengikuti langkah-langkah pendekatan sistem karena tugas-tugas tersebut mengikuti pola yang teratur dan dilakukan secara top down.

Pembangunan sistem hanyalah salah satu dari rangkaian daur hidup suatu sistem. Meskipun demikian, proses ini merupakan aspek yang sangat penting. Kita akan melihat berapa fase/tahapan dari daur hidup suatu sistem.

a. Mengenali adanya kebutuhan

Sebelum segala sesuatunya terjadi, timbul suatu kebutuhan atau problema yang harus dikenali sebagaimana adanya. Kebutuhan dapat terjadi sebagai hasil perkembangan dari organisasi dan volume yang meningkat melebihi 
kapasitas dari sistem yang ada. Semua kebutuhan ini harus dapat didefinisikan dengan jelas. Tanpa adanya kejelasan dari kebutuhan yang ada, pembangunan sistem akan kehilangan arah dan efektifitasnya.

b. Pembangunan Sistem

Suatu proses atau seperangkat prosedur yang harus diikuti untuk menganalisis kebutuhan yang timbul dan membangun suatu sistem untuk dapat memenuhi kebutuhan tersebut.

c. Pemasangan Sistem

Setelah tahap pembangunan sistem selesai. Sistem kemudian akan dioperasikan. Pemasangan sistem merupakan tahap yang penting pula dalam daur hidup sistem. Peralihan dari tahap pembangunan menuju tahap operasional terjadi pemasangan sistem yang sebenarnya, yang merupakan langkah akhir dari suatu pembangunan sistem.

d. Pengoperasian Sistem

Program-program komputer dan prosedur-prosedur pengoperasian yang membentuk suatu sistem informasi semuanya bersifat statis, sedangkan organisasi ditunjang oleh sistem informasi tadi. Ia selalu mengalami perubahan-perubahan itu karena pertumbuhan kegiatan bisnis, perubahan peraturan, dan kebijakan ataupun kemajuan teknologi. Untuk mengatasi perubahan-perubahan tersebut, sistem harus diperbaiki atau diperbaharui.

e. Sistem Menjadi Usang

Kadang perubahan yang terjadi begitu drastis sehingga tidak dapat diatasi hanya dengan melakukan perbaikan-perbaikan pada sistem yang berjalan. Tibalah saatnya secara ekonomis dan teknis sistem yang ada sudah tidak layak lagi untuk dioperasikan dan sistem yang baru perlu dibangun untuk menggantinya.

Sistem informasi kemudian akan melanjutkan daur hidupnya. Sistem dibangun untuk memenuhi kebutuhan yang muncul. Sistem beradaptasi terhadap perubahan-perubahan lingkungannya yang dinamis. Sampailah pada kondisi di mana sistem tersebut tidak dapat lagi beradaptasi dengan perubahan-perubahan yang ada ataupun secara ekonomis tidak layak lagi untuk dioperasikan. Sistem yang baru kemudian dibangun untuk menggantikannya. Untuk dapat menggambarkan daur hidup sistem ini, lihat gambar dibawah ini.

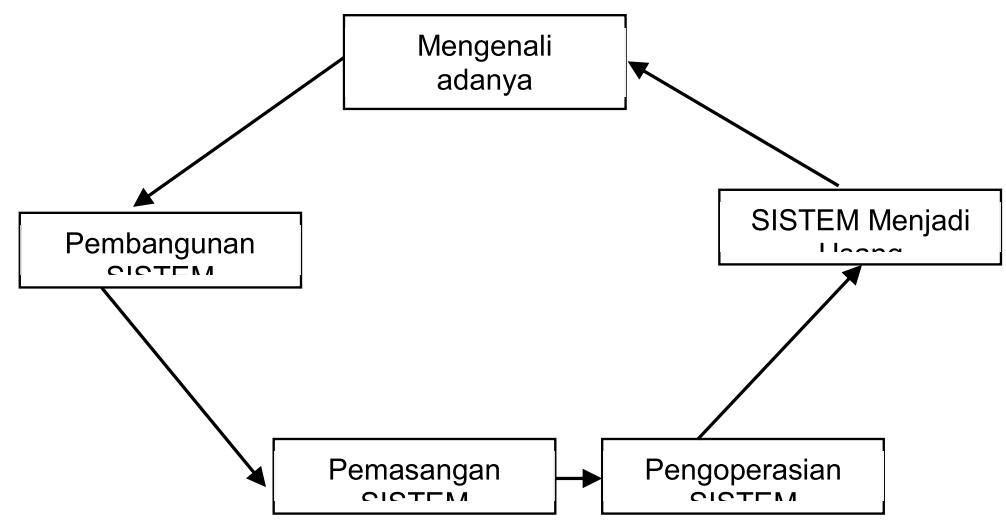




\author{
Gambar 2.1 Daur Hidup Sistem \\ Sumber: Buku Sistem Informasi Manajemen (2003:15)
}

\title{
Pemodelan Sistem Statement Of Purpose
}

Model pertama yang dibahas adalah Statement of Purpose (STP), yang berisi deskripsi tekstual fungsi sistem. Hal ini berguna bagi hampir semua level antara lain level puncak, level pemakai, dan level yang tidak terlibat secara langsung dalam pengembangan sistem. STP hanya terdiri dari satu, dua atau lebih kalimat. Tetapi sebaiknya tidak lebih dari satu paragraf, karena tidak digunakan untuk mendeskripsikan sistem secara detil. Deskripsi detail menjadi tanggung-jawab aspek pemodelan berikutnya.

\section{Data Flow Diagram Context Level (Context Diagram)}

Pohan (1997:11) mengemukakan bahwa context diagram adalah kasus khusus DFD (bagian dari DFD yang berfungsi memetakan model lingkaran), yang direpresentasikan dengan lingkaran tunggal yang mewakili keseluruhan sistem. Context diagram menyoroti sejumlah karakteristik penting sistem yaitu:

a. Kelompok pemakai, organisasi atau sistem lain dimana sistem kita melakukan komunikasi yang disebut juga terminator.

b. Data masuk, data yang diterima sistem dari lingkungan dan harus diproses dengan cara tertentu.

c. Data keluar, data yang dihasilkan sistem kita dan diberikan ke dunia luar.

d. Penyimpanan data (data store) yang digunakan secara bersama antara sistem kita dengan terminator. Data ini dapat dibuat oleh sistem dan digunakan oleh lingkungan atau sebaliknya, dibuat oleh lingkungan dan digunakan oleh sistem kita. Hal ini berarti pembuatan simbol data store dalam context diagram dibenarkan, dengan syarat simbol tersebut merupakan bagian dari dunia di luar sistem.

e. Batasan, antara sistem kita dan lingkungan (rest of the world).

\section{Sintaks dan Fungsi Simbol DFD}

Ada beberapa sintaks yang berlaku untuk semua smbol DFD yaitu antara lain:

a. Komponen Proses

a) Proses menunjukan transformasi dari masukan menjadi keluaran dan biasanya komponen proses dapat disimbolkan dengan lingkaran atau persegi empat tumpul.

b) Dalam proses umumnya didefinisikan dengan kalimat sederhana atau kata tunggal.

c) Nama lingkaran tersebut mendeskripsikan respon yang harus dilakukan system dalam menganalisa keadaan.

b. Komponen aliran data

a) Menggambarkan gerakan paket data atau informasi dari satu bagian ke bagian lain dari sistem.

b) Aliran data direpresentasikan dengan menggunakan anak panah.

c) Nama fungsi untuk menjelaskan arti dalam aliran tersebut dan ditulis untuk mengidentifikasikan aliran tersebut.

d) Ujung panah menunjukan arah data bergerak. 
e) Aliran data yang digambarkan sebagai panah dengan dua ujung menggambarkan terjadinya dialog.

f) Aliran data dapat menyebar atau menyatu.

c. Komponen penyimpan

a) Dipakai untuk memodelkan kumpulan data, misalnya paket data, tape magnetis, disk dan model DBMS (Database Management System).

b) Penyimpanan direpresentasikan dengan garis paralel atau segi empat terbuka.

d. Komponen Entiti Luar

a) Merupakan bagian luar sistem, aliran data yang dihubungkan dengan entiti luar dan menunjukan hubungan antara sistem dengan dunia luar.

b) Entiti luar direpresentasikan dengan empat persegi panjang.

Data dictionary atau disebut juga DD. DD tidak menggunakan notasi grafis sebagaimana halnya DFD, tetapi porsinya dalam memodelkan sistem tidak perlu diragukan lagi karena sebuah model tidak lengkap tanpa DD. Mirip dengan kamus yang membantu kita dalam mencari arti kata baru, maka DD juga mempunyai fungsi yang sama dalam pemodelan sistem. Selain itu DD berfungsi membantu pelaku sistem untuk mengerti aplikasi secara detail, dan mereorganisasi semua elemen data yang digunakan dalam sistem secara presisi sehingga pemakai dan penganalisa sistem punya dasar pengertian yang sama tentang masukan, keluaran, penyimpanan dan proses.

Entity-relationship diagram (ERD) adalah model konseptual yang mendeskripsikan hubungan antar penyimpan (dalam DFD). ERD digunakan untuk memodelkan struktur data dan hubungan antar data, karena hal ini relatif kompleks.

\section{Hubungan}

Entiti dapat berhubungan satu sama lain. Hubungan ini dinamakan relationship (relasi). Sebagaimana halnya entiti maka dalam hubunganpun harus dibedakan antara hubungan atau bentuk hubungan antar entiti dengan isi dari hubungan itu sendiri.

\section{Cardinality Rasio}

Cardinality Rasio yaitu menjelaskan batasan pada jumlah entiti yang berhubungan melalui suatu relationship.

\section{System Procedure Diagram}

Digunakan untuk mendefinisikan hubungan antara bagian (pelaku proses), proses (manual atau berbasis komputer) dan aliran data (dalam bentuk dokumen keluaran, dan masukan).

\section{Subsistem}

Rosiyadi (2007:3) mengungkapkan bahwa Bagian terkecil dari sistem adalah subsistem atau elemen. Subsistem adalah bagian dari sebuah sistem dan merupakan hasil pengunsuran (factoring), Penyederhanaan (Simplikasi) dan Pemisah (decoupling). 


\section{Konsep Dasar Informasi}

Sutabri (2003:41) mengungkapkan bahwa informasi adalah data yang telah diklasifikasi atau diolah atau diinterprestasi untuk digunakan dalam proses pengambilan keputusan. Sistem pengolahan informasi mengolah data menjadi informasi atau tepatnya mengolah data dari bentuk tak berguna menjadi berguna bagi penerimanya.

Sutabri (2003:42) mendefinisikan bahwa

"Sistem Informasi adalah suatu sistem di dalam suatu organisasi yang mempertemukan kebutuhan pengolahan transaksi harian yang mendukung fungsi operasi organisasi yang bersifat manajerial dengan kegiatan strategi dari suatu organisasi untuk dapat menyediakan kepada pihak luar tertentu dengan laporan-laporan".

Sistem informasi terdiri dari komponen-komponen yang disebut blok bangunan (building block), yeng terdiri dari blok masukan, blok model, blok keluaran, blok teknologi, blok basis data, dan blok kendali. Sebagai suatu sistem, keenam blok tersebut masing-masing saling berinteraksi satu dengan yang lain membentuk satu kesatuan untuk mencapai sasaran.

a. Blok masukan (input block)

Input mewakili data yang masuk ke dalam sistem informasi. Input di sini termasuk metode dan media untuk menangkap data yang akan dimasukan, yang dapat berupa dokumen-dokumen dasar.

b. Blok Model (model block)

Blok ini terdiri dari kombinasi prosedur, logika, dan model matematik yang akan memanipulasi data input dan data yang tersimpan di basis data dengan cara yang sudah tertentu untuk menghasilkan keluaran yang diinginkan.

c. Blok keluaran (output blok)

Produk dari sistem informasi adalah keluaran yang merupakan informasi yang berkualitas dan dokumentasi yang berguna untuk semua tingkatan manajemen serta semua pemakai.

d. Blok Teknologi (technology block)

Teknologi merupakan "toolbox" dalam sistem informasi. Teknologi digunakan untuk menerima input, menjalankan model, menyimpan dan mengakses data, menghasilkan dan mengirimkan keluaran, dan membantu pengendalian dari sistem secara keseluruhan. Teknologi terdiri dari 3 (tiga) bagian utama, yaitu (brainware), perangkat lunak (software), dan perangkat keras (hardware).

e. Blok basis data (database block)

Basis data (database) merupakan kumpulan data yang saling berkaitan dan berhubungan satu dengan yang lain, tersimpan di perangkat keras komputer dan menggunakan perangkat lunak untuk memanipulasinya. Data perlu disimpan dalam basis data untuk keperluan penyediaan informasi lebih lanjut. Data di dalam basis data perlu diorganisasikan sedemikian rupa supaya informasi yang dihasilkan berkualitas. Organisasi basis data yang baik juga berguna untuk efisiensi kapasitas penyimpannya. Basis data diakses atau dimanipulasi menggunakan perangkat lunak paket yang disebut DBMS (database management system). 


\section{f. Blok kendali (control block)}

Banyak hal yang dapat merusak sistem informasi, seperti bencana alam,api, temperatur, air. debu, kecurangan-kecurangan, kegagalan-kegagalan itu sendiri, ketidak efisienan, sabotase, dan lain sebagainya. Beberapa pengendalian perlu dirancang dan diterapkan untuk menyakinkan bahwa halhal yang dapat merusak sisten dapat dicegah ataupun bila terlanjur terjadi kesalahan-kesalahan dapat langsung cepat diatasi.

Fungsi-fungsi system informasi sangat diperlukan dalam pencapaian tujuan sustu system. Fungsi-fungsi itu terdiri dari input (masukan), Processing (proses), Output (Keluaran), Storage (penyimpanan) dan Control (pengendalian) dapat disingkat IPOSC

a. Fungsi-fungsi masukan menggambarkan aktifitas-aktifitas dalam pengaksesan data.

b. Fungsi-fungsi proses menggambarakan manipulasi atau transformasi terhadap data yang diterima dari fungsi-fungsi input.

c. Fungsi-fungsi keluaran menggambarkan aktifitas-aktifitas yang diperlukan dalam menghasilkan suatu informasi atau laporan.

d. Fungsi-fungsi penyimpanan menggambarkan aktifitas-aktifitas yang diperlukan dalam mengolah data-data sistem.

e. Fungsi-fungsi pengendalian menggambarkan aktifitas-aktifitas otomatis maupun manual untuk melakukan verifikasi dan validasi terhadap masukan dan keluaran. Serta menjaga integritas penyimpanan data.

Komponen-komponen system informasi terdiri dari People (orang), Procedure (prosedur), Data (data), Software (Perangkat lunak), dan Hardware (perangkat keras) dapat disingkat PPDSH

a. People (orang), komponen ini dapat dibagi kedalam tiga jenis yaitu users, designers dan implementers (keen \& Cummins, 1994). Users adalah orang yang mempunyai pengetahuan yang tinggi tentang suatu system tapi mempunyai keahlian teknis yang rendah, designer adalah orang yang pengetahuan tentang suatu system dan keahlian teknisnya seimbang sedangkan implementer adalah orang yang mempunyai keahlian teknis yang tinggi tapi mempunyai pengetahuan tentang system yang rendah.

b. Procedure (prosedur) adalah sekumpulan instruksi yang sangat diperlukan oleh people (orang) dalam suatu organisasi untuk melaksanakan pekerjaaannya.

c. Data (data) adalah core dari sebuah system informasi.

d. Software (perangkat lunak) adalah sekumpulan instruksi logic yang memberitahu computer tentang apa yang harus dikerjakan.

e. Hardware (perangkat keras) adalah perangkat fisik yang diperlukan dalam pengoperasian perangkat lunak.

Perancangan sistem informasi yang diterjemahkan dari information system planning (ISP) menceritakan bagaimana menerapkan pengetahuan tentang sistem informasi ke dalam organisasi. Sistem informasi dapat dibentuk sesuai kebutuhan organisasi masing-masing. Oleh karena itu, untuk dapat menerapkan sistem yang 
efektif dan efisien diperlukan perencanaan, pelaksanaan, pengaturan dan evaluasi sesuai keinginan dan nilai masing-masing organisasi.

Untuk memahami bagaimana merencanakan system informasi yang tepat dan sesuai dengan organisasi masing-masing, berikut dibahas bagaimana informasi itu mengalir dari satu tempat ke tempat lain lain, bagaimana merencanakan sistem informasi secara keseluruhan, serta bagaimana merencanakan sistem informasi secara per bagian.

\section{$\mathrm{IDE} \rightarrow$ DESIGN $\rightarrow$ PELAKSANAAN $\rightarrow$ EVALUASI}

\section{Pendekatan Waterfall}

Ladjamudin (2006:16) mengungkapkan bahwa model waterfall telah diperoleh dari proses engineering lainnya. Model ini menawarkan cara pembuatan perangkat lunak secara lebih nyata. Langkah-langkah yang penting dalam model ini adalah :

\section{a. Penentuan dan analisis spesifikasi}

Jasa, kendala dan tujuan dihasilkan dari konsultasi dengan pengguna sistem. Kemudian semuanya itu dibuat dalam bentuk yang dapat dimengerti oleh user dan staf pengembang.

\section{b. Desain sistem dan perangkat lunak}

Proses desain sistem membagi kebutuhan-kebutuhan menjadi sistem perangkat lunak atau perangkat keras. Proses tersebut menghasilkan sebuah arsitektur sistem keseluruhan. Desain perangkat lunak termasuk menghasilkan fungsi sistem perangkat lunak dalam bentuk yang mungkin ditransformasi ke dalam satu atau lebih program yang dapat di jalankan.

\section{c. Implementasi dan uji coba unit}

Selama tahap ini desain perangkat lunak disadari sebagai sebuah program lengkap atau unit program. Uji unit termasuk pengujian bahwa setiap unit sesuai spesifikasi.

\section{d. Integrasi dan uji coba sistem}

Unit program diintegrasikan dan diuji menjadi sistem yang lengkap untuk menyakinkan bahwa persyaratan perangkat lunak telah dipenuhi. Setelah uji coba, sistem disampaikan ke konsumen.

\section{e. Operasi dan Pemeliharaan}

Masalah pendekatan waterfall adalah ketidakluwesan pembagian proyek kedalam langkah yang nyata atau jelas. Namun demikian model waterfall mencerminkan kepraktisan engeneering. Konsekwensinya, model proses perangkat lunak yang berdasarkan pada pendekatan ini digunakan dalam pengembangan sistem perangkat lunak dan hardware yang luas. Langkahlangkah penting tersebut dalam bentuk gambar dapat dilihat pada gambar dibawah ini:

Pada PT. Sempurna Jasa Kami/eXis terdapat beberapa istilah-istilah yang berhubungan dengan bidang jasa antaran kurir sebagai berikut:

\section{a. Kurir / Pengantar}


Kurir/Pengantar adalah Seseorang yang bertugas mengantarkan atau menyampaikan surat kepada customer sesuai dengan wilayahnya.

b. Sortir

Sortir adalah suatu kegiatan mengklasifikasikan surat berdasarkan wilayahnya.

c. BT (Bukti Terima)

BT adalah tanda bukti kiriman surat, dokumen dan paket kepada penerima (tujuan) untuk antaran wilayah Bandung raya.

d. BST (Bukti Serah Terima)

BST adalah bukti serah terima surat, dokumen dan paket dari petugas pick up kepada pelanggan.

e. Investigasi

Investigasi adalah suatu kegiatan menelusuri kebenaran proses antaran.

f. Antaran

Antaran adalah surat, dokumen/majalah dan paket yang harus diantarkan atau disampaikan dari pengirim ke penerima.

g. Retur

Retur adalah staus surat, dokumen/majalah dan paket yang tidak terantar oleh kurir.

h. Pick up

Pick up adalah pelayanan pengambilan surat, dokumen/majalah dan paket dari konsumen.

i. POD (Personal Order Delivery)

POD adalah tanda bukti untuk antaran luar kota dalam proses pengiriman surat, dokumen dan paket sebagai panduan agen dalam proses pengiriman.

j. Manifest

Manifest adalah ringkasan dari POD yang berisi identitas penerima serta tujuan surat.

Tjiptono (1996:6) mendefinisikan bahwa

"Jasa adalah setiap tindakan atau perbuatan yang dapat ditawarkan oleh suatu pihak kepada pihak lain, yang pada dasarnya bersifat intangible (tidak berwujud fisik) dan tidak menghasilkan kepemilikan sesuatu".

\section{Metode Penelitian}

\section{Metode System Development Life Cycle (SDLC)}

Model SDLC atau Sekuensial Linier sering disebut juga Model Air Terjun. Model ini mengusulkan sebuah pendekatan perkembangan perangkat lunak yang sistematik dan sekunsial yang dimulai pada tingkat dan kemajuan sistem pada seluruh analisis, desain, kode, pengujian, dan pemeliharaan

Model ini disusun bertingkat, setiap tahap dalam model ini dilakukan berurutan, satu sebelum yang lainnya. Model ini biasanya digunakan untuk membuat sebuah software dalam skala besar dan yang akan dipakai dalam waktu yang lama. Sangat cocok untuk pengembangan sistem yang besar. Tidak sesuai atau tidak terlalu disarankan untuk small scale project_karena Resource intensive, tidak fleksibel, sulit untuk aplikasi dengan perubahan cara pengambilan keputusan yang cepat 


\section{Tahapan-tahapan (SDLC):}

a. Fase Perencanaan Sistem

Dalam tahapan ini dibentuk suatu struktur kerja strategis yang luas dan pandangan sistem informasi baru yang jelas yang akan memenuhi kebutuhan-kebutuhan pemakai informasi. Proyek sistem dievaluasi dan dipisahkan berdasarkan prioritasnya. Proyek dengan prioritas tertinggi akan dipilih untuk pengembangan. Penyediaan sumber daya baru dan penyediaan dana untuk pengembangan sistem. Rencana kerja yang matang juga disusun untuk menjalankan tahapan-tahapan lainnya. Hasil dari tahapan ini adalah : Langkah-langkah detail rencana kerja dan penugasan untuk anggota tim.

\section{b. Fase Analisis Sistem}

Dilakukan proses penilaian, identifikasi dan evaluasi komponen dan hubungan timbal-balik yang terkait dalam pengembangan system: definisi masalah, tujuan, kebutuhan, prioritas dan kendala-kendala system, ditambah identifikasi biaya, keuntungan dan estimasi jadwal untuk solusi yang berpotensi.

\section{c. Fase Perancangan Sistem secara Umum}

Dibentuk alternatif-alternatif perancangan konseptual untuk pandangan pemakai. Alternatif ini merupakan perluasan kebutuhan pemakai. Alternatif perancangan konseptual memungkinkan manajer dan pemakai untuk memilih rancangan terbaik yang cocok untuk kebutuhan mereka.

Pada fase ini analis sistem mulai merancang proses dengan mengidentifikasikan laporan-laporan dan output yang akan dihasilkan oleh sistem yang diusulkan. Data masing-masing laporan ditentukan. Biasanya, perancang sistem membuat sketsa form atau tampilan yang mereka harapkan bila sistem telah selesai dibentuk. Sketsa ini dilakukan pada kertas atau pada tampilan komputer.

\section{d. Fase Evaluasi dan Seleksi Sistem}

Akhir fase perancangan sistem secara umum menyediakan point utama untuk keputusan investasi. Oleh sebab itu dalam fase evaluasi dan seleksi sistem ini nilai kualitas sistem dan biaya/keuntungan dari laporan dengan proyek system dinilai secara hati-hati dan diuraikan dalam laporan evaluasi dan seleksi sistem.

\section{e. Fase Perancangan Sistem secara Detail}

Pada fase ini semua komponen dirancang dan dijelaskan secara detail. Perencanaan output (layout) dirancang untuk semua layar, form-form tertentu dan laporan-laporan yang dicetak. Semua output direview dan disetujui oleh pemakai dan didokumentasikan.

Berdasarkan perancangan output dan input, proses-proses dirancang untuk mengubah input menjadi output. Transaksi-transaksi dicatat dan dimasukkan secara online atau batch. Macam-macam model dikembangkan untuk mengubah data menjadi informasi. Prosedur ditulis untuk membimbing pemakai dan pesonel operasi agar dapat bekerja dengan sistem yang sedang dikembangkan.

Database dirancang untuk menyimpan dan mengakses data. Kendalikendali yang dibutuhkan untuk melindungi sistem baru dari macammacam ancaman dan error ditentukan. 


\section{f. Fase Implementasi Sistem dan Pemeliharaan Sistem}

Sistem siap untuk dibuat dan diinstalasi.

Sejumlah tugas harus dikoordinasi dan dilaksanakan untuk implementasi sistembaru.

\section{Pembahasan}

Dalam kegiatan penelitian yang lakukan di PT. Sempurna Jasa Kami/eXis, ada beberapa kendala-kendala yang terjadi di bagian pemrosesan data tepatnya pada pembuatan laporan, pembuatan laporan ini masih melakukan proses manual yaitu proses copy dan proses edit terlebih dahulu sebelum di cetak, dikarenakan di PT. Sempurna Jasa Kami/eXis mempunyai program aplikasi yang terpisah dalam proses entri data dan pembuatan laporan. Proses entri data menggunakan program aplikasi Visual Basic sedangkan laporannya menggunakan aplikasi web sehingga untuk pembuatan laporan harus melakukan copy dan edit dari aplikasi web ke Microsoft Excel. Akibat dari permasalahan tersebut kinerja bagian pemrosesan data di PT. Sempurna Jasa Kami/eXis tidak efektif dan efisien. Kendala selanjutnya yaitu dalam keamanan database, keamanan database tidak terjamin karena setiap user dapat mengakses semua form.

Permasalahan yang terjadi di PT. Sempurna Jasa Kami/eXis ini, maka berupaya memberikan solusi terhadap permasalahan tersebut yaitu dengan cara memperbaiki sistem yang sedang berjalan.

\section{Sistem Usulan}

Berdasarkan analisis masalah yang telah diuraikan, maka mengusulkan sistem informasi jasa antaran kurir, diharapkan dapat membantu dalam pemrosesan data sehingga proses kerja di PT. Sempurna Jasa Kami/eXis lebih efektif dan lebih baik.

Sistem usulan ini digambarkan dalam bentuk system procedure. Gambar sistem usulan dapat dilihat dibawah ini. 


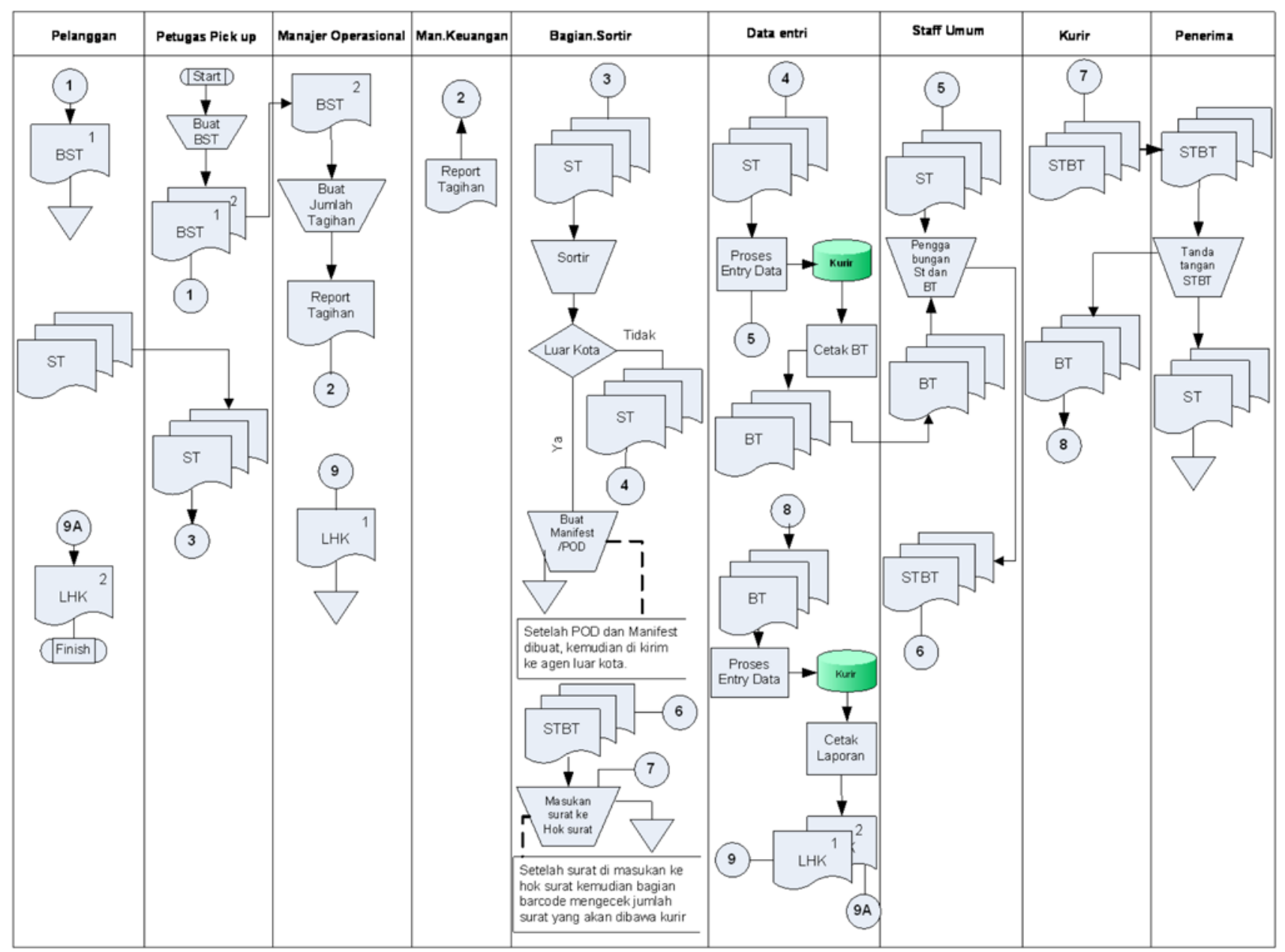

Gambar 4.1

Flow map Usulan

\section{Kesimpulan}

Penerapan merupakan kegiatan memperoleh dan mengintegrasikan sumber daya fisik dan konseptual yang menghasilkan suatu sistem yang bekerja. Adapun tugas implementasi digambarkan dalam gambar dibawah ini: 


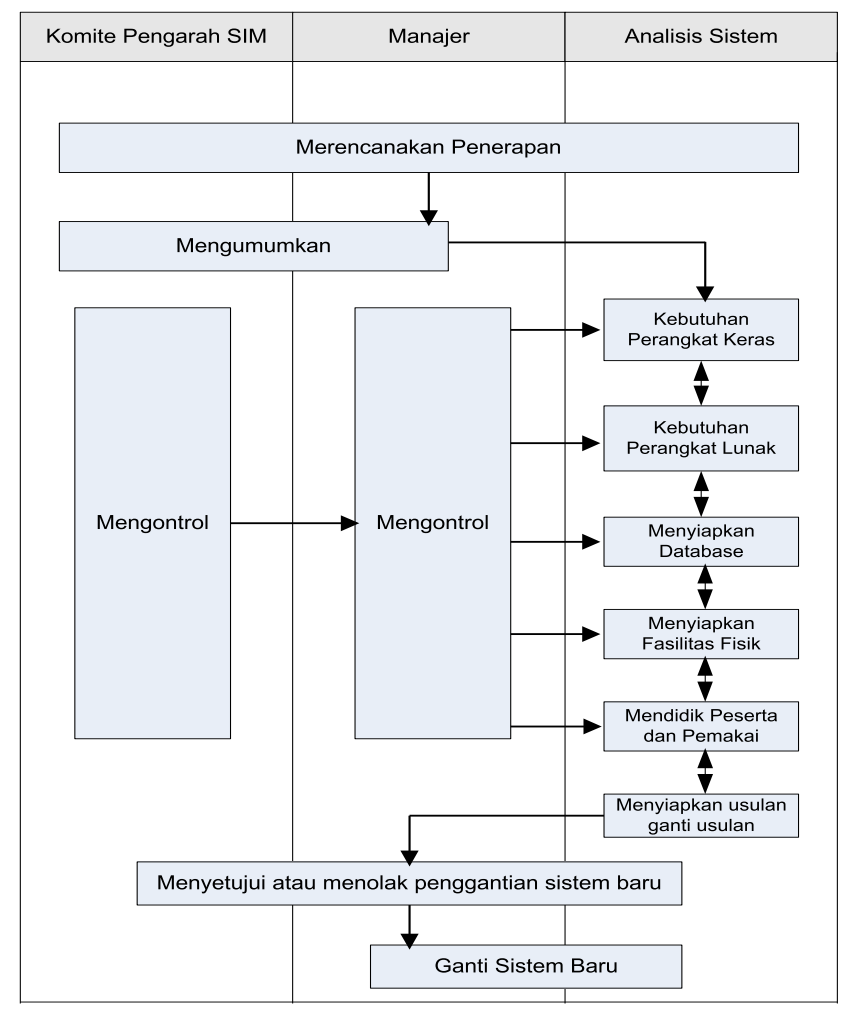

Gambar 5.1 Tahapan Impelmentasi Sistem

Sumber : Buku Sistem Informasi Manajemen (2003:289)

Sebelum sistem baru digunakan, manajer harus memahami dengan baik pekerjaaan yang diperlukan untuk menerapkan rancangan sistem. Sebuah rancangan penerapan perlu dilakukan dengan cara pengujian pada suatu aplikasi yang akan digunakan agar mengetahui apa saja yang harus dikembangkan.

Proyek penerapan diumumkan kepada para pegawai dengan cara yang sama seperti pada penelitian sistem. Tujuan pengumuman ini adalah menginformasikan dan mensosialisasikan kepada karyawan mengenai keputusan untuk menerapkan system baru dan meminta kerja sama pegawai.

Kebutuhan perangkat keras harus mendukung dengan kebutuhan aplikasi yang akan dioperasikan. Adapun spesifikasi perangkat keras adalah sebagai berikut:

Processor

Memory

Hard disk

Motherboard

Display

VGA Card
: $\quad$ Minimum $1.00 \mathrm{Ghz}$, Rekomendasi $2.00 \mathrm{GHz}$ keatas

: $\quad$ Minimum $128 \mathrm{MB}$, Rekomendasi $256 \mathrm{MB}$ keatas

: $\quad 40 \mathrm{~GB}$ atau lebih tinggi

: Minimum 800x600 256 colors, Rekomendasi $1024 \times 768$ highest 32 bit

: NVIDIA GeForce4 MX 440 with AGP8X 


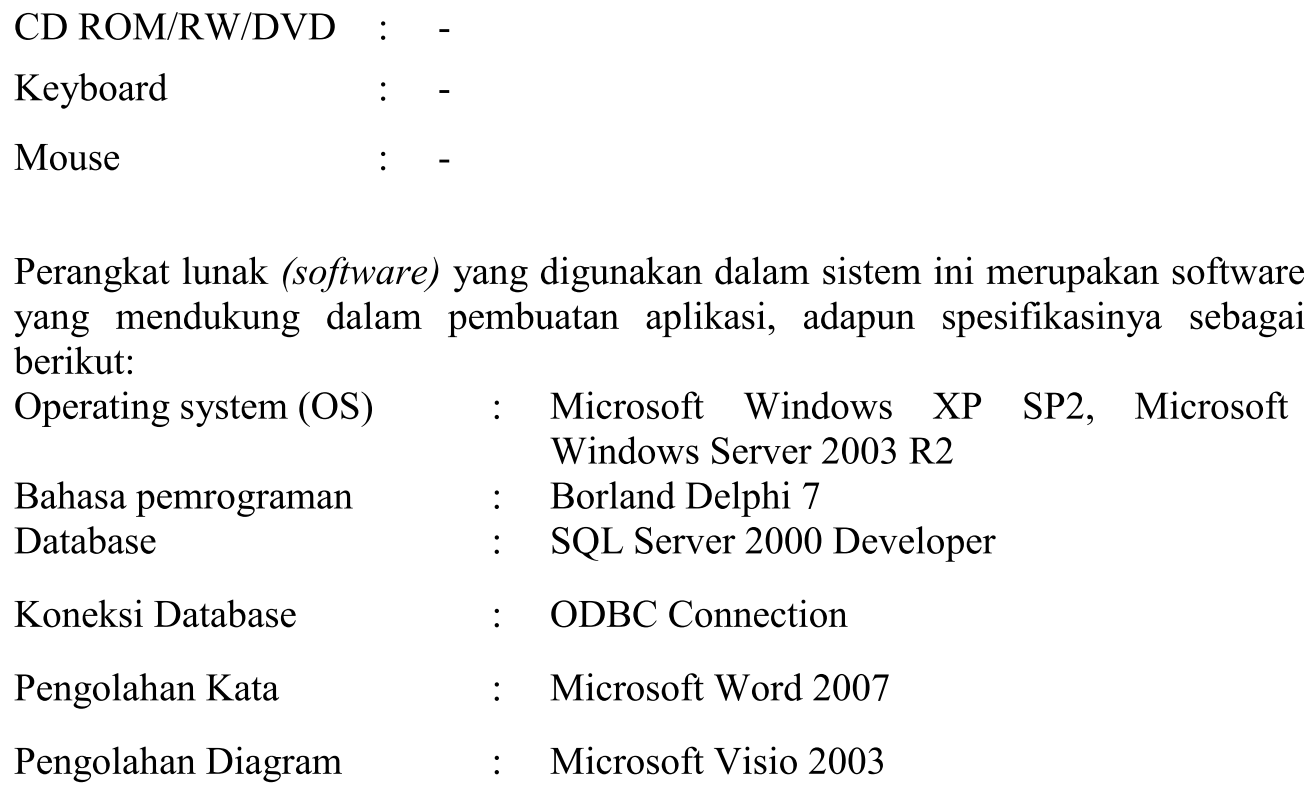

DBA bertanggung jawab untuk semua kegiatan yang berhubungan dengan data dan ini mencakup persiapan database.

Jika perangkat keras sistem baru tidak sesuai dengan fasilitas yang ada, perlu dilakukan konstruksi baru atau perombakan. Ruang komputer yang menyimpan komputer berskala besar merupakan kombinasi yang rumit dari pengendalian suhu dan kelembaban yang khusus, keamanan dan pemadam kebakaran dan sebagainya.

Sistem baru kemungkinan besar akan menpengaruhi banyak orang. Beberapa orang akan membuat sistem bekerja. Mereka ini disebut peserta dan mereka meliputi operator pemasukan data dan pegawai administrasi lainnya. Semua orang ini harus dididik tentang peran mereka dalam sistem. Pendidikan harus dijadwalkan jauh setelah siklus hidup dimulai dan pada sistem ini disedianan manual book sebagai panduan menjalankan aplikasi. Adapun kebutuhan sumber daya manusia pada sistem ini adalah:

1. Administrator

Bertanggung jawab atas semua sistem, pemeliharaan database, menentukan data master seperti menentukan data wilayah, data tarif, data jenis antaran dan data status kirim, pemeliharaan data serta menentukan kebutuhan aplikasi. Adapun pengguna sebagai administrator pada sistem ini adalah General Manager dan Manager Operational.

2. Operator

Bertugas mengoperasikan aplikasi, pemrosesan data seperti proses input data, edit data dan pembuatan laporan. Adapun pengguna sebagai operator pada sistem ini adalah bagian entry data. 


\section{Daftar Pustaka}

[1] Fathansyah, Basis Data, Bandung, Informatika Bandung, 1999

[2] Kuliah umum http://www.IlmuKomputer.com

[3] Ladjamudin B, Al-bahra, Rekayasa Perangkat Lunak, Yogyakarta, Graha Ilmu, 2006

[4] Martina, Inge, 36 Jam Belajar Komputer Microsoft SQL Server 2000, Jakarta, PT.Elex Media Komputindo, 2003

[5] Martina, Inge, 36 Jam Belajar Komputer Pemograman Visual Borland Delphi7, Jakarta, Elex Media Komputindo, 2004

[6] Musalini, Uus Membangun Aplikasi Super Cantik dan Full Animasi dengan

[7] Delphi.Jakarta, Elex Media Komputindo, 2004

[8] Pohan, Husni, Iskandar, Pengantar Perancangan Sistem, Jakarta, Erlangga, 1997

[9] Rosiyadi, Didi, Analisis dan Desain Sistem Informasi, Bandung, Rosiyadi, 2007

[10] Sutabri ,Tata, Sistem Informasi Manajemen, Yogyakarta, Andi, 2005

[11] Tjiptono, Fandy, Manajemen Jasa. Yogyakarta, Andi, 1996

[12] Widianti, Sri, Basis Data, Jakarta, LP3I, 2000 